\title{
Itch Signaling in the Nervous System
}

Joseph Jeffry, Seungil Kim, and Zhou-Feng Chen

Center for the Study of Itch, Departments of Anesthesiology, Psychiatry and Developmental Biology, Washington University School of Medicine Pain Center, St. Louis, MO 63110, USA. chenz@wustl.edu

\section{Abstract \\ Itch is a major somatic sensation, along with pain, temperature and touch, detected and relayed by the somatosensory system. Itch can be an acute sensation, associated with mosquito bite, or a chronic condition, like atopic dermatitis $(29,59)$. The origins of the stimulus can be localized in the periphery or systemic, and associated with organ failure or cancer. Itch is also a perception originating in the brain. Itch is broadly characterized as either histamine-dependent (histaminergic) or histamine-independent (nonhistaminergic), both of which are relayed by subsets of C-fibers, and by the second-order neurons expressing gastrin-releasing peptide receptor (GRPR) and spinothalamic track (STT) neurons in the spinal cord of rodents. Historically, itch research has been primarily limited to clinical and psychophysical studies, and to histamine- mediated mechanisms. In contrast, little is known about signaling mechanisms underlying nonhistaminergic itch, despite the fact that the majority of chronic itch are mediated by nonhistaminergic mechanisms. During the past few years, important progress has been made in understanding of molecular signaling of itch, largely due to the introduction of mouse genetics. In this review, we examine some of molecular mechanisms underlying itch sensation with an emphasis on recent studies in rodents.}

\section{Histaminergic itch signaling}

Since the discovery of histamine as a substance released from the skin in response to noxious stimuli (44), histamine has remained one of the best known pruritogens, and its signaling mechanism is relatively better understood compared with that for other pruritogens. Histamine can evoke both itch and pain sensations $(6,37)$. Mice lacking histamine receptor 1 (H1R) exhibited profound deficits in pain perception across a wide range of modalities, including acute and inflammatory models (49). Histamine is only marginally involved in chronic itch, and most types of chronic itch are refractory to antihistamines. Histamine excites a subset of unmyelinated C-fibers innervating the skin and the signals are transmitted to the superficial layers of the dorsal spinal cord. These peripheral inputs then ascend to the thalamus through the anterolateral pathway and proceed to the somatosensory and the anterior cingulate cortex $(18,50)$.

\section{A. Histamine receptor signaling}

Histamine receptors are members of the G protein-coupled receptors (GPCR) and four receptors $\mathrm{H} 1 \sim 4 \mathrm{R}$ have been identified (26). H1R is a major receptor implicated in itch sensation. H1R is coupled with $\mathrm{G}_{\mathrm{q}}$ proteins and activates phospholipase C (PLC) (4).

\footnotetext{
Address for reprint requests and other correspondence: Zhou-Feng Chen, Center for the Study of Itch, Department of Anesthesiology, Washington University, St. Louis, MO 63110 (chenz@wustl.edu).

DISCLOSURES

No conflicts of interest, financial or otherwise, are declared by the authors.
} 
Activation of H1R increases calcium levels in cultured rat sensory neurons and this is attenuated by a PLC inhibitor, U73122, and by calcium-free extracellular conditions (38, 54). In rat dorsal root ganglion (DRG) neurons H1R activation also stimulates phospholipase A2 (PLA2) and lipoxygenase (LOX), which result in a release of LOX metabolite 12HEPTE (38). Evidence indicates that H1R exerts its effect through activation of transient receptor potential cation channel V1 (TRPV1), an ion channel for transducing a plethora of external stimuli such as heat, protons and capsaicin $(10,35,38)$. Diacylglycerol (DAG), a product of PLC $\beta$ hydrolysis, can bind the capsaicin binding site and directly activate TRVP1 channel in rat DRG neurons (80), consistent with the finding that H1R is coupled to TRPV1 through $\mathrm{G}_{\mathrm{q}}$ signaing. The connection between histamine and TRPV1 is also supported by the finding that histamine-induced $\mathrm{Ca}^{2+}$ response in rat DRG neurons is attenuated by TRPV1 antagonists (38). Further genetic studies indicated that mice lacking TRPV1 exhibited impaired scratching response to histamine injection (67). Importantly, histamine evokes inward currents only when TRPV1 and H1R are coexpressed, but not when either of which is expressed alone in HEK 293 cells (67). Together, these studies favor a molecular link between H1R and TRPV1.

PLC $\beta 3$, a PLC isozyme, has been shown to be important for mediating histamine-induced $\mathrm{Ca}^{2+}$ flux and scratching behavior via H1R in DRG neurons (25). The PLC $\beta 3$ pathway is also required for mediating serotonin (5-HT) and $\alpha-\mathrm{Me}-5$-HT-evoked scratching (30). In contrast, scratching induced by injection of endothelin-1 (ET-1), a potent pruritogen mediated by two endothelin receptors $\mathrm{ET}_{\mathrm{A}} \mathrm{R}$ and $\mathrm{ET}_{\mathrm{B}} \mathrm{R}$ (16), remained the same in mice lacking PLC $\beta 3$. In fact, it is debatable if ET-1-evoked scratching is dependent on histamine release (48). Scratching evoked by a-Me-5-HT and ET-1 is not reduced in mice lacking TRPV1, suggesting that TRPV1 does not act as a pruritogenic effector for these two pathways (30). This is intriguing given that $\mathrm{ET}_{\mathrm{A}} \mathrm{R}$ and TRPV1 are co-expressed in DRG neurons and the former can potentiate TRPV1-evoked current and sensitize nociception (51, 60). It is possible that $\mathrm{ET}_{\mathrm{A}} \mathrm{R}$ acts through TRPV1 only in nociceptive processing, but not in pruriceptive processing. It is also possible that different members of a signal transduction molecule downstream of GPCRs may be involved in response to algogens versus pruritogens. PLC $\beta 3$ was suggested to be dispensable for pain behavior (30), but the finding that mice lacking PLC $\beta 3$ showed enhanced morphine-induced analgesia in terms of heatevoked pain behavior suggests that PLC $\beta 3$ action is not itch-specific (81). These results highlight the complexity of that multiple intracellular signaling transduction pathways downstream of H1R that exist in DRG neurons, and it may be too simplistic to say which H1R-mediated signal pathway is involved in itch, and which is in pain.

Several recent studies have implicated H4R in chronic itch, particularly in allergic and inflammatory states $(5,12,20,77)$. However, most of these studies have been focused on non-neuronal mechanisms. Although there may be a difference between H1R and H4R pharmacology and molecular signaling in itch, it remains unclear if differences of these two histamine receptors may be attributable to their association with TRPV1. Only limited literature concerning involvement of $\mathrm{H} 2 \mathrm{R}$ and $\mathrm{H} 3 \mathrm{R}$ in itch is available (66). $\mathrm{H} 2 \mathrm{R}$ is coupled with $\mathrm{G}_{\mathrm{s}}$ and produces cAMP (4). In female BalbC mice, $\mathrm{H} 2 \mathrm{R}$ agonist (dimaprit) failed to cause scratching and H2R antagonist (cimetidine) could not inhibit histamine-induced itch in mice (5). H3R is linked to $\mathrm{Ga}_{\mathrm{i} / \mathrm{o}}$ and inhibits cAMP production (43). However, it is unclear whether H3R is expressed in DRGs. One study suggested no expression of H3R in mouse sensory neurons (28), whereas the other indicated its expression as detected by RT-PCR (35). Interestingly, intradermal injection of H3R antagonists induced scratching in normal mice and in mice with mast cell deficiency (28). Since H3R antagonists such as clobenpropit are also H4R agonists, these results suggest that H4R-mediated itch is not dependent on histamine release from mast cells. It appears the contribution of $\mathrm{H} 2$ and $\mathrm{H} 3$ receptors to peripherally induced itch transmission is minimal. 


\section{Nonhistaminergic itch signaling}

Many types of chronic itch cannot be relieved by anti-histamine treatments, and thus are likely to be mediated by nonhistaminergic mechanisms. Here we focus on two nonhistaminergic pruritogens, cowhage and chloroquine (CQ), and potential underlying molecular mechanisms.

\section{A. Cowhage and PAR signaling}

Cowhage is a classic nonhistaminergic pruritogen that causes intense itch when injected into the skin (65). In both humans and non-human primates, insertion of cowhage spicules activates mechanically sensitive $\mathrm{C}$ fibers, whereas histamine activates $\mathrm{C}$ fibers that are mechanically insensitive $(32,33,52,64)$. Unlike histamine, itch mediated by cowhage is not accompanied by weal, flare and redness (33). In the spinal cord of primates, histamine and cowhage activate separate populations of lamina I STT neurons (18). The component of cowhage that causes itch is a cysteine protease called mucunain, which activates the protease activated receptors-2 and 4 (PAR-2, PAR-4) (61). Four PARs (PAR1 4) have been identified, and all are GPCR family members (27). Cleavage of the $\mathrm{N}$ terminus of the receptor generates a tethered ligand activating PAR itself $(57,73)$. Mast cell tryptase acts on PAR2, trypsin on PAR2 and PAR4, and thrombin acts on PAR1, PAR3, and PAR4 $(72,78)$. PAR1, 2, and 4 have been implicated in itch with PAR2/4 mediating nonhistaminergic itch (78). PAR2/4 act through the $\mathrm{G}_{\mathrm{q}}$ protein and $\mathrm{Ca}^{2+}$ signaling, whereas PAR1/PAR3 may have different mechanisms because they cannot be activated by mucunain as examined by $\mathrm{Ca}^{2+}$ signaling. It is unclear whether these PARs are also important for other types of pruritic response.

Clinical relevance of PAR2 in chronic itch has been suggested by the finding that PAR2 expression is increased in the skin of AD patients (72), and in a dry skin model (1). In addition, dry skin-related scratching can be attenuated by PAR2 antibody (1). Approximately 40 60\% of unmyelinated small DRG neurons co-express substance P (SP), calcitonin gene-related peptide (CGRP) and PAR2 (73). In the mouse dry skin model, the percentage of DRG neurons expressing PAR-2 is increased and receptor activity, measured by cytosolic $\mathrm{Ca}^{2+}$ flux, is potentiated (1). Although signal transduction pathways downstream of PAR2 in pruriceptive transmission are poorly understood, it is noteworthy that several TRP channels have been suggested to be effectors of PAR2 in nociceptive processing. PAR2 and TRPV4 are coexpressed in peptidergic DRG neurons, and PAR2 agonist evoked TRPV4-mediated $\mathrm{Ca}^{2+}$ signaling and currents in cultured DRG neurons can be blocked by PLC $\beta$ antagonist (22). PAR2 may act through TRPV4 in mechanical hyperalgesia (22). Moreover, PAR2 is functionally linked to TRPA1 (15), a channel activated by cold, mustard oil and cannabinoids $(34,74)$. Approximately $80 \%$ of TRPA1 ${ }^{+}$ cells express PAR2, whereas 56\% of PAR2 ${ }^{+}$cells express TRPA1. In HEK 293 cells expressing TRPA1 and in DRG neurons, PAR2 activation potentiates currents evoked by TRPA1 agonists, and this potentiation can be attenuated by PLC inhibitors or phosphatidylinositol-4,5-bisphosphate (PIP(2)), but not by inhibiting protein kinase C (PKC) activity (15). Agonists of PAR2 also increased afferent signaling by sensitizing TRPV1. In addition to peripherally mediated primary hyperalgesia, this phenomenon may involve secondary hyperalgesia due to central sensitization $(2,14,79)$. TRPV1 is coexpressed with PAR2, but not with PAR1 or PAR3 in DRG neurons. In contrast to TRPA1, inhibitors of both PLC and PKC suppressed PAR2-induced sensitization of TRPV1 such as $\mathrm{Ca}^{2+}$ signaling and TRPV1 currents (2). These results suggest that there are multiple PAR2mediated intracellular signaling pathways for nociceptive processing. Thus, it is likely that some TRP channels may be downstream effectors of PAR2 in pruriceptive processing as well. 


\section{B. Chloroquine and MrgprA3}

CQ is a drug used to treat malaria. A prevalent side effect, particularly in Africans, is systemic pruritus (70). The itch is often intolerable and is not responsive to antihistamines. MrgprA3, one of Mas related G protein-coupled receptors, has recently been suggested to mediate CQ-induced itch in mouse DRG neurons (45). Mrgprs are orphan GPCR family members comprising about $50 \mathrm{Mrgprs}$ in mouse and they can be grouped into several subfamilies (19). MrgprAs, MrgprB5, MrgprC11 and MrgprD are expressed in subsets of small diameter DRG and trigeminal ganglia. Human MrgprXs are also expressed in DRG neurons suggesting that Mrgprs may have some conserved roles in somatosensation (45). The identity of the endogenous activators is not clear, although they are activated by RFamide peptides that have analgesic effects in vivo (58). Targeted disruption of the Mrgprs gene cluster including dozens of members in mice resulted in enhanced mechanical and thermal pain hypersensitivity, indicating that Mrgprs may constitute an endogenous inhibitory system for nociceptive transmission (23). In contrast, these mutant mice also displayed reduced CQ-induced itch responses but histamine-induced itch was not affected (45). CQ mediated activation of MrgprA3 causes a rise in cytosolic $\mathrm{Ca}^{2+}$ in HEK 293 cells expressing the receptor. Electrophysiological experiments confirm that CQ could induce action potentials in a small population of DRG neurons and this required MrgprA3. These data suggest that MrgprA3 is a candidate receptor for CQ-induced itch. However, it is unclear whether MrgprA3 has an indirect role in itch induction as a component of endogenous pain inhibitory system. MrgprA3 is co-expressed with GRP, raising the possibility that activation of MrgprA3 by CQ may promote GRP release from C-fibers and stimulate $\mathrm{GRPR}^{+}$neurons in the spinal cord (45). MrgprA3 is expressed by 4 5\% of DRG neurons, and is a $\mathrm{G}_{\mathrm{q}}$ linked GPCR. However, the specific downstream signaling pathway of MrgprA3 remains to be determined. PLC $\beta 3$ is unlikely to be involved in CQ-MrgprA3 signaling given that CQ induced itch is normal in mice lacking PLC $\beta 3$ (30). Since CQmediated itch is partially attenuated in mice lacking Mrgpr cluster, it is possible that other Mrgprs may also be required for CQ-induced itch in vivo. Likewise, it will be interesting to identify the specific PLC isoform that is downstream of Mrgpr and is required for mediating CQ-dependent itch in the future.

\section{GRPR signaling}

GRP is a mammalian homolog of amphibian bombesin, a polypeptide initially isolated from the skin of the frog Bombina bombina $(7,31)$. GRP is a 27 amino acid peptide that targets a metabotropic receptor, GRPR, that is also referred to as BB2. The other two closely related mammalian bombesin peptide-like receptors are BB1 or neuromedin $\mathrm{B}$ receptor (NMBR) that prefers to bind neuromedin $B$ (NMB) and BB3, an orphan bombesin receptor subtype 3 (BRS3) (31). These receptors are all GPCR members, and have been implicated in a wide range of physiological activities including feeding, smooth muscle contraction and regulation of sucrose intake $(40,55)$. Mice lacking GRPR are grossly normal, suggesting that GRPR is not required for animal survival (24). NMBR is important for thermoregulation, but not necessary for smooth muscle contraction, or for suppression of feeding behavior (56). In the CNS, the physiological effect of GRPR has been studied in the anterior cingulated cortex, hippocampus and amygdala $(8,42,69)$. In all these structures GRPR is expressed by inhibitory interneurons and GRPR mutant mice showed enhanced long-term potentiation and more persistent long-term fear memory.

In the DRG neurons, GRP is coexpressed with CGRP, SP but not in Bandaireae simplicifolia isolectin B4 (IB4) ${ }^{+}$fibers nor in myelinated fibers. Approximately $80 \%$ of $\mathrm{GRP}^{+}$fibers express TRPV1, and project to lamina I and $\mathrm{II}_{\mathrm{O}}$ of the dorsal spinal cord (75). GRP is also colocalized with MrgprA3 (45), suggesting that it may be an itch-specific neurotransmitter required for nonhistaminergic pruriceptive transmission. GRP is also 
colocalized with Toll-like receptor 7 (TLR7) that is necessary for mediating scratching evoked by a variety of pruritogens including CQ, PAR2 agonist, ET-1, 5-HT and imiquimod (IMQ), a TLR7 agonist (46). However, another investigation did not find scratching deficits in TLR7 knockout mice (39). They also showed that IMQ evoked normal scratching in these mutant mice, raising the question of whether IMQ acts through TLR7 (39). It remains to be determined whether the discrepancy between these two studies is due to the dose of pruritogens used or other factors.

GRPR is expressed in a subset of lamina I neurons of the spinal cord, and does not overlap with neurons expressing neurokinin 1 receptor found in a majority of STT neurons. Interestingly, scratching behaviors induced by injection of bombesin into various species of animals were observed decades ago. Many earlier studies show that injection of bombesin into the brain or spinal cord evoked scratching/grooming behavior in a variety of animal species (mice, rats, guinea pigs, rabbits and monkeys) $(11,21,36)$. While underlying molecular mechanisms were unknown at that time, the pharmacological studies strongly imply that bombesin-induced scratching is a widely conserved behavior in animal phyla. Recent mouse genetic studies have begun to implicate GRPR as a key receptor for pruriceptive transmission in the spinal cord. Mice lacking GRPR exhibited compromised scratching behavior to intradermal injection of compound 48/80, a PAR2 agonist and CQ, but not to 5-HT, histamine and ET-1 injections (76). Intrathecal injection of a GRPR antagonist also inhibited scratching behavior evoked by a few pruritogens, and by intrathecal injection of GRP. In contrast, GRPR mutant mice displayed normal heat, mechanical and chemical pain behavior. These studies argue that activation of GRPR signaling is important for nonhistaminergic pruriceptive transmission, but is largely dispensable for histaminergic itch. The partial attenuation of scratching behaviors in GRPR mutant mice implies that GRPR is not the sole itch receptor in the spinal cord. One likely explanation for this is that other mammalian bombesin receptor homologues such as neuromedin B receptor (NMBR) may compensate for the loss of GRPR in the spinal cord to varying degree depending on the type of pruritogenic stimulus.

The importance of GRPR as an itch receptor is further reinforced by two recent studies of the role of vesicular glutamate transporter 2 (VGLUT2) in itch $(41,47)$. In primary afferent fibers, loading of glutamate into synaptic vesicles is primarily mediated by VGLUT2. Preventing the expression of this transporter thereby inhibits synaptic glutamate release. VGLUT2 in nociceptors is important for mediating acute pain, especially heat hypersensitivity because mice lacking VGLUT2 showed reduced heat pain $(41,63)$. In contrast, mice lacking VGLUT2 in primary afferents expressing either TRPV1 or Nav1.8, the tetrodotoxin-resistant sodium channel subunit, exhibited enhanced pruriceptive transmission manifested by spontaneous scratching and increased scratching in response to several pruritogens $(41,47)$. Interestingly, mice lacking both VGLUT2 and GRPR showed attenuated scratching behaviors relative to mice lacking VGLUT2 only, indicating that GRPR is a central mediator that can account for at least part of enhanced itch signaling (41). Furthermore, activation of c-fos in $\mathrm{GRPR}^{+}$neurons was observed in these mutant mice, suggesting a change of GRPR ${ }^{+}$neuronal activity (47). These results are in marked contrast with a reduced firing of lamina I neurons in response to heat and mechanical stimuli in VGLUT2 conditional knockout mice (63). Therefore, GRPR appears to be an integral component of central itch signaling that is essential for relaying peripheral itch information to the brain, and GRPR ${ }^{+}$neurons could be different from those lamina I nociceptive neurons responsible for mediating noxious thermal and mechanical pain mediated by glutmate release in the spinal cord.

The function of GRPR ${ }^{+}$neurons was studied using intrathecal injection of the targeted cytotoxin, saporin conjugated to bombesin. Since bombesin binds to GRPR, it would permit 
the ablation of the dorsal horn neurons that express GRPR (76). Ablation of GRPR ${ }^{+}$dorsal horn neurons produced a marked scratching deficit in response to all pruritogens tested, both histamine dependent and histamine independent, but it did not affect pain behavior (76). This study provides evidence that dorsal horn neurons that express GRPR are not required to sense pain. While GRPR is more selectively involved in nonhistaminergic itch, the dorsal horn neurons that express GRPR relay both histaminergic and nonhistaminergic itch signals (76). These studies suggest an existence of a labeled line for itch at the level of the dorsal horn that sends itch-specific information to the brain. The striking contrasting phenotype of itch and pain in mice lacking GRPR ${ }^{+}$neurons poses several important questions: Do GRPR ${ }^{+}$ neurons project to the brain or they are interneurons or both ? The most unexpected finding is that loss of GRPR ${ }^{+}$neurons appears to disable the function of STT neurons that is presumably directly required for ascending transmission of pruritic information. This leads to another question: what is the function of STT neurons in pruriceptive transmission? Is there a subset of dorsal horn neurons that transmits pain signal exclusively to the brain, in a manner analogous to $\mathrm{GRPR}^{+}$neurons ? What is the identity of the receptor for histaminedependent itch in GRPR ${ }^{+}$neurons? Nonetheless, the identification of $\mathrm{GRPR}^{+}$neurons argues that it is the spinal cord circuit that is required for discriminating itch from pain signals.

Other neuronal signaling pathways in the spinal cord-STT neurons have long been known to mediate both itch and pain signals $(17,29)$. Approximately $80 \sim 85 \%$ of STT neurons in lamina I of the spinal cord express neurokinin 1 receptor (NK1R) (71).

Pharmacological ablation of NK1 $\mathrm{R}^{+}$neurons in the spinal cord of rats by the use of SPsaporin attenuated both 5-HT-induced scratching and chronic pain behavior $(9,53)$. These data provide functional evidence supporting that $\mathrm{NK}_{1} \mathrm{R}^{+}$neurons and $\mathrm{GRPR}^{+}$neurons are distinct populations, as the ablation of the latter in the spinal cord had no impact on 5-HTinduced scratching nor on nociceptive transmission (76). Although NK1R in primary afferents was implicated in nonhistaminergic itch (3), little is known about its role in central processing of itch. Mice lacking SP encoded by the preprotachykinin A gene exhibited normal scratching response to 5-HT (13). However, whether these mutant mice have deficits in response to other types of pruritic stimuli is unclear.

The function of dorsal horn inhibitory interneurons expressing transcription factor Bhlhb5 in itch has recently been studied in mice. Loss of these neurons during development resulted in an enhanced pruriceptive transmission (62). Using a cheek model that permits more specific differentiation between itch and pain response (68), Ross et al found that formalin induced scratching instead of wiping, suggesting a switch from nociceptive to pruriceptive transmission in these mutant mice. In addition, the licking/flinching behavior in the second phase of the formalin test was increased. Given that licking/flinching behavior may also have itch component under certain conditions, one plausible explanation is that enhanced licking/flinching is suggestive of a central sensitization of itch. Bhlhb5-expressing inhibitory circuit may exert the action through inhibiting GRPR signaling or GRPR ${ }^{+}$neuronal activity. A more detailed analysis of pain behaviors is necessary for addressing whether these inhibitory neurons are also involved in other aspects of nociceptive transmission.

\section{Concluding remarks}

Recent studies of several putative itch-specific receptors and identification of subsets of dorsal horn neurons that are important for pruriceptive transmission in mice have set the stage for molecular and cellular deciphering of itch sensation. It is worth noting that research on itch signaling is still at its infancy, and basic mechanisms by which pruriceptive transmission is regulated have yet to be fully understood. At the molecular level, an emerging theme is that GPCR signaling is central to pruriceptive transmission, and each pruritogen is likely to provoke itch sensation through a unique GPCR signaling transduction 
pathway. Increasing evidence also points to the fact that many GPCRs important for itch also regulate PLC/Ca ${ }^{2+}$ signaling in nociceptive processing. Thus, multiple intracellular signal transduction pathways required for pruriception are likely to converge, crosstalk and even compete with nociceptive signaling in various settings. The findings that many pruritogens also activate nociceptive signaling in primary afferents and many classical "pure" algogens have been shown to be able to evoke itch underscore the complexity of the sensory transduction pathway that underlies sensation leading to scratching or withdrawal responses. This raises an important question of how pruriceptive and nociceptive signaling emanating from the same ligand is dissociated from each other. One of the major challenges is to understand how a specific $\mathrm{Ca}^{2+}$ signaling pathway is activated in response to an itch vs. pain stimulus, how $\mathrm{Ca}^{2+}$ signaling instructs downstream channels such as TRP channels to compute a specific signal into neuronal outputs for itch or pain. Accumulating evidence suggests that distinct isoforms or isozymes of signaling transduction components may be the key for differentiating between itch and pain signaling. While a GPCR may be coupled to different types of channels to mediate itch vs. pain response, modality-specific signaling is likely to be dependent on cell types in which a receptor is expressed. Indeed, much evidence has been suggested that GPCR signaling results in tissue specific responses, even those emanating from the same GPCR subtype. Since most GPCRs activated by individual pruritogens are expressed in many other tissues in addition to sensory neurons, it needs to be defined in future as to which signaling process contributes to itch and in which cell.

While pain research has no doubt provided illuminating insights into the fundamental mechanisms whereby the somatosensory system is able to detect and transmit external noxious stimuli from the periphery to the brain, it is the revelation of the differences between itch and pain signaling that would ultimately prove to be the key to answering why an itch is an itch and not pain. At the cellular level, it is important to determine whether itchspecific or pain-specific primary afferents exist, even though they may share some aspects of molecular expression profile. In the spinal cord, we need to establish the relationship between $\mathrm{GRPR}^{+}$neurons and STT neurons, and how these neurons relay itch to the brain. With the aid of mouse genetics, the door for improving mechanistic understanding of itch signaling and neural circuits has opened, and it is our hope that some of GPCRs implicated in pruriceptive transmission may be potential targets that can be translated into novel therapeutics for chronic itch in the future.

\section{Acknowledgments}

\section{GRANTS}

This work was supported by National Institute of Health Grant RO1 AR056318-01A1 (to Z.F. Chen). J. Jeffry is supported by NIDA training grant 5 T32 DA007261-19.

\section{References}

1. Akiyama T, Carstens MI, Carstens E. Enhanced scratching evoked by PAR-2 agonist and 5-HT but not histamine in a mouse model of chronic dry skin itch. Pain. 2010

2. Amadesi S, Nie J, Vergnolle N, Cottrell GS, Grady EF, Trevisani M, Manni C, Geppetti P, McRoberts JA, Ennes H, Davis JB, Mayer EA, Bunnett NW. Protease-activated receptor 2 sensitizes the capsaicin receptor transient receptor potential vanilloid receptor 1 to induce hyperalgesia. J Neurosci. 2004; 24:4300-4312. [PubMed: 15128844]

3. Andoh T, Nagasawa T, Satoh M, Kuraishi Y. Substance P induction of itch-associated response mediated by cutaneous NK1 tachykinin receptors in mice. J Pharmacol Exp Ther. 1998; 286:11401145. [PubMed: 9732370]

4. Bakker RA, Timmerman H, Leurs R. Histamine receptors: specific ligands, receptor biochemistry, and signal transduction. Clin Allergy Immunol. 2002; 17:27-64. [PubMed: 12113220] 
5. Bell JK, McQueen DS, Rees JL. Involvement of histamine H4 and H1 receptors in scratching induced by histamine receptor agonists in Balb C mice. Br J Pharmacol. 2004; 142:374-380. [PubMed: 15066908]

6. Broadbent JL. Observations on histamine-induced pruritus and pain. Br J Pharmacol Chemother. 1955; 10:183-185. [PubMed: 14389658]

7. Brown M, Marki W, Rivier J. Is gastrin releasing peptide mammalian bombesin? Life Sci. 1980; 27:125-128. [PubMed: 7401928]

8. Cao X, Mercaldo V, Li P, Wu LJ, Zhuo M. Facilitation of the inhibitory transmission by gastrinreleasing peptide in the anterior cingulate cortex. Mol Pain. 2010; 6:52. [PubMed: 20836873]

9. Carstens EE, Carstens MI, Simons CT, Jinks SL. Dorsal horn neurons expressing NK-1 receptors mediate scratching in rats. Neuroreport. 2010; 21:303-308. [PubMed: 20125052]

10. Caterina MJ, Schumacher MA, Tominaga M, Rosen TA, Levine JD, Julius D. The capsaicin receptor: a heat-activated ion channel in the pain pathway [see comments]. Nature. 1997; 389:816-824. [PubMed: 9349813]

11. Cowan A, Khunawat P, Zhu XZ, Gmerek DE. Effects of bombesin on behavior. Life Sci. 1985; 37:135-145. [PubMed: 2409426]

12. Cowden JM, Zhang M, Dunford PJ, Thurmond RL. The histamine H4 receptor mediates inflammation and pruritus in Th2-dependent dermal inflammation. J Invest Dermatol. 2010; 130:1023-1033. [PubMed: 19907432]

13. Cuellar JM, Jinks SL, Simons CT, Carstens E. Deletion of the preprotachykinin A gene in mice does not reduce scratching behavior elicited by intradermal serotonin. Neurosci Lett. 2003; 339:72-76. [PubMed: 12618303]

14. Dai Y, Moriyama T, Higashi T, Togashi K, Kobayashi K, Yamanaka H, Tominaga M, Noguchi K. Proteinase-activated receptor 2-mediated potentiation of transient receptor potential vanilloid subfamily 1 activity reveals a mechanism for proteinase-induced inflammatory pain. J Neurosci. 2004; 24:4293-4299. [PubMed: 15128843]

15. Dai Y, Wang S, Tominaga M, Yamamoto S, Fukuoka T, Higashi T, Kobayashi K, Obata K, Yamanaka H, Noguchi K. Sensitization of TRPA1 by PAR2 contributes to the sensation of inflammatory pain. J Clin Invest. 2007; 117:1979-1987. [PubMed: 17571167]

16. Davenport AP. International Union of Pharmacology. XXIX. Update on endothelin receptor nomenclature. Pharmacol Rev. 2002; 54:219-226. [PubMed: 12037137]

17. Davidson S, Giesler GJ. The multiple pathways for itch and their interactions with pain. Trends Neurosci. 2010; 33:550-558. [PubMed: 21056479]

18. Davidson S, Zhang X, Yoon CH, Khasabov SG, Simone DA, Giesler GJ Jr. The itch-producing agents histamine and cowhage activate separate populations of primate spinothalamic tract neurons. J Neurosci. 2007; 27:10007-10014. [PubMed: 17855615]

19. Dong X, Han S, Zylka MJ, Simon MI, Anderson DJ. A diverse family of GPCRs expressed in specific subsets of nociceptive sensory neurons. Cell. 2001; 106:619-632. [PubMed: 11551509]

20. Dunford PJ, Williams KN, Desai PJ, Karlsson L, McQueen D, Thurmond RL. Histamine H4 receptor antagonists are superior to traditional antihistamines in the attenuation of experimental pruritus. J Allergy Clin Immunol. 2007; 119:176-183. [PubMed: 17208599]

21. Gmerek DE, Cowan A. Studies on bombesin-induced grooming in rats. Peptides. 1983; 4:907-913. [PubMed: 6143301]

22. Grant AD, Cottrell GS, Amadesi S, Trevisani M, Nicoletti P, Materazzi S, Altier C, Cenac N, Zamponi GW, Bautista-Cruz F, Lopez CB, Joseph EK, Levine JD, Liedtke W, Vanner S, Vergnolle N, Geppetti P, Bunnett NW. Protease-activated receptor 2 sensitizes the transient receptor potential vanilloid 4 ion channel to cause mechanical hyperalgesia in mice. J Physiol. 2007; 578:715-733. [PubMed: 17124270]

23. Guan Y, Liu Q, Tang Z, Raja SN, Anderson DJ, Dong X. Mas-related G-protein-coupled receptors inhibit pathological pain in mice. Proc Natl Acad Sci U S A. 2010; 107:15933-15938. [PubMed: 20724664]

24. Hampton LL, Ladenheim EE, Akeson M, Way JM, Weber HC, Sutliff VE, Jensen RT, Wine LJ, Arnheiter H, Battey JF. Loss of bombesin-induced feeding suppression in gastrin-releasing peptide receptor-deficient mice. Proc Natl Acad Sci U S A. 1998; 95:3188-3192. [PubMed: 9501238] 
25. Han SK, Mancino V, Simon MI. Phospholipase Cbeta 3 mediates the scratching response activated by the histamine $\mathrm{H} 1$ receptor on C-fiber nociceptive neurons. Neuron. 2006; 52:691-703. [PubMed: 17114052]

26. Hill SJ, Ganellin CR, Timmerman H, Schwartz JC, Shankley NP, Young JM, Schunack W, Levi R, Haas HL. International Union of Pharmacology. XIII. Classification of histamine receptors. Pharmacol Rev. 1997; 49:253-278. [PubMed: 9311023]

27. Hollenberg MD, Compton SJ. International Union of Pharmacology. XXVIII. Proteinase-activated receptors. Pharmacol Rev. 2002; 54:203-217. [PubMed: 12037136]

28. Hossen MA, Inoue T, Shinmei Y, Fujii Y, Watanabe T, Kamei C. Role of substance P on histamine H(3) antagonist-induced scratching behavior in mice. J Pharmacol Sci. 2006; 100:297302. [PubMed: 16603804]

29. Ikoma A, Steinhoff M, Stander S, Yosipovitch G, Schmelz M. The neurobiology of itch. Nat Rev Neurosci. 2006; 7:535-547. [PubMed: 16791143]

30. Imamachi N, Park GH, Lee H, Anderson DJ, Simon MI, Basbaum AI, Han SK. TRPV1-expressing primary afferents generate behavioral responses to pruritogens via multiple mechanisms. Proc Natl Acad Sci U S A. 2009; 106:11330-11335. [PubMed: 19564617]

31. Jensen RT, Battey JF, Spindel ER, Benya RV. International Union of Pharmacology. LXVIII. Mammalian bombesin receptors: nomenclature, distribution, pharmacology, signaling, and functions in normal and disease states. Pharmacol Rev. 2008; 60:1-42. [PubMed: 18055507]

32. Johanek LM, Meyer RA, Friedman RM, Greenquist KW, Shim B, Borzan J, Hartke T, LaMotte $\mathrm{RH}$, Ringkamp M. A role for polymodal C-fiber afferents in nonhistaminergic itch. J Neurosci. 2008; 28:7659-7669. [PubMed: 18650342]

33. Johanek LM, Meyer RA, Hartke T, Hobelmann JG, Maine DN, LaMotte RH, Ringkamp M. Psychophysical and physiological evidence for parallel afferent pathways mediating the sensation of itch. J Neurosci. 2007; 27:7490-7497. [PubMed: 17626210]

34. Jordt SE, Bautista DM, Chuang HH, McKemy DD, Zygmunt PM, Hogestatt ED, Meng ID, Julius D. Mustard oils and cannabinoids excite sensory nerve fibres through the TRP channel ANKTM1. Nature. 2004; 427:260-265. [PubMed: 14712238]

35. Kajihara Y, Murakami M, Imagawa T, Otsuguro K, Ito S, Ohta T. Histamine potentiates acidinduced responses mediating transient receptor potential V1 in mouse primary sensory neurons. Neuroscience. 2010; 166:292-304. [PubMed: 20006972]

36. Katz R. Grooming elicited by intracerebroventricular bombesin and eledoisin in the mouse. Neuropharmacology. 1980; 19:143-146. [PubMed: 7189017]

37. Keele CAaA, D. Substances producing pain and itch. Baltimore: Williams \& Wilkins; 1964. p. 288-304.

38. Kim BM, Lee SH, Shim WS, Oh U. Histamine-induced $\mathrm{Ca}(2+)$ influx via the PLA(2)/ lipoxygenase/TRPV1 pathway in rat sensory neurons. Neurosci Lett. 2004; 361:159-162. [PubMed: 15135918]

39. Kim SJ, Park GH, Kim D, Lee J, Min H, Wall E, Lee CJ, Simon MI, Lee SJ, Han SK. Analysis of cellular and behavioral responses to imiquimod reveals a unique itch pathway in transient receptor potential vanilloid 1 (TRPV1)-expressing neurons. Proc Natl Acad Sci U S A. 2011

40. Kroog GS, Jensen RT, Battey JF. Mammalian bombesin receptors. Med Res Rev. 1995; 15:389417. [PubMed: 8531502]

41. Lagerstrom MC, Rogoz K, Abrahamsen B, Persson E, Reinius B, Nordenankar K, Olund C, Smith C, Mendez JA, Chen ZF, Wood JN, Wallen-Mackenzie A, Kullander K. VGLUT2-dependent sensory neurons in the TRPV1 population regulate pain and itch. Neuron. 2010; 68:529-542. [PubMed: 21040852]

42. Lee K, Dixon AK, Gonzalez I, Stevens EB, McNulty S, Oles R, Richardson PJ, Pinnock RD, Singh L. Bombesin-like peptides depolarize rat hippocampal interneurones through interaction with subtype 2 bombesin receptors. J Physiol. 1999; 518(Pt 3):791-802. [PubMed: 10420015]

43. Leurs R, Bakker RA, Timmerman H, de Esch IJ. The histamine H3 receptor: from gene cloning to H3 receptor drugs. Nat Rev Drug Discov. 2005; 4:107-120. [PubMed: 15665857] 
44. Lewis T, Zotterman Y. Vascular reactions of the skin to injury: Part VIII. The resistance of the human skin to constant currents, in relation to injury and vascular response. J Physiol. 1927; 62:280-288. [PubMed: 16993850]

45. Liu Q, Tang Z, Surdenikova L, Kim S, Patel KN, Kim A, Ru F, Guan Y, Weng HJ, Geng Y, Undem BJ, Kollarik M, Chen ZF, Anderson DJ, Dong X. Sensory neuron-specific GPCR Mrgprs are itch receptors mediating chloroquine-induced pruritus. Cell. 2009; 139:1353-1365. [PubMed: 20004959]

46. Liu T, Xu ZZ, Park CK, Berta T, Ji RR. Toll-like receptor 7 mediates pruritus. Nat Neurosci. 2010; 13:1460-1462. [PubMed: 21037581]

47. Liu Y, Abdel Samad O, Zhang L, Duan B, Tong Q, Lopes C, Ji RR, Lowell BB, Ma Q. VGLUT2dependent glutamate release from nociceptors is required to sense pain and suppress itch. Neuron. 2010; 68:543-556. [PubMed: 21040853]

48. McQueen DS, Noble MA, Bond SM. Endothelin-1 activates ETA receptors to cause reflex scratching in BALB/c mice. Br J Pharmacol. 2007; 151:278-284. [PubMed: 17351652]

49. Mobarakeh JI, Sakurada S, Katsuyama S, Kutsuwa M, Kuramasu A, Lin ZY, Watanabe T, Hashimoto Y, Yanai K. Role of histamine H(1) receptor in pain perception: a study of the receptor gene knockout mice. Eur J Pharmacol. 2000; 391:81-89. [PubMed: 10720638]

50. Mochizuki H, Tashiro M, Kano M, Sakurada Y, Itoh M, Yanai K. Imaging of central itch modulation in the human brain using positron emission tomography. Pain. 2003; 105:339-346. [PubMed: 14499452]

51. Motta EM, Chichorro JG, Rae GA. Role of ET(A) and ET(B) endothelin receptors on endothelin-1-induced potentiation of nociceptive and thermal hyperalgesic responses evoked by capsaicin in rats. Neurosci Lett. 2009; 457:146-150. [PubMed: 19429182]

52. Namer B, Carr R, Johanek LM, Schmelz M, Handwerker HO, Ringkamp M. Separate peripheral pathways for pruritus in man. J Neurophysiol. 2008; 100:2062-2069. [PubMed: 18562548]

53. Nichols ML, Allen BJ, Rogers SD, Ghilardi JR, Honore P, Luger NM, Finke MP, Li J, Lappi DA, Simone DA, Mantyh PW. Transmission of chronic nociception by spinal neurons expressing the substance P receptor. Science. 1999; 286:1558-1561. [PubMed: 10567262]

54. Nicolson TA, Bevan S, Richards CD. Characterisation of the calcium responses to histamine in capsaicin-sensitive and capsaicin-insensitive sensory neurones. Neuroscience. 2002; 110:329-338. [PubMed: 11958874]

55. Ohki-Hamazaki H, Iwabuchi M, Maekawa F. Development and function of bombesin-like peptides and their receptors. Int J Dev Biol. 2005; 49:293-300. [PubMed: 15906244]

56. Ohki-Hamazaki H, Sakai Y, Kamata K, Ogura H, Okuyama S, Watase K, Yamada K, Wada K. Functional properties of two bombesin-like peptide receptors revealed by the analysis of mice lacking neuromedin B receptor. J Neurosci. 1999; 19:948-954. [PubMed: 9920658]

57. Ossovskaya VS, Bunnett NW. Protease-activated receptors: contribution to physiology and disease. Physiol Rev. 2004; 84:579-621. [PubMed: 15044683]

58. Panula P, Kalso E, Nieminen M, Kontinen VK, Brandt A, Pertovaara A. Neuropeptide FF and modulation of pain. Brain Res. 1999; 848:191-196. [PubMed: 10612711]

59. Paus R, Schmelz M, Biro T, Steinhoff M. Frontiers in pruritus research: scratching the brain for more effective itch therapy. J Clin Invest. 2006; 116:1174-1186. [PubMed: 16670758]

60. Plant TD, Zollner C, Mousa SA, Oksche A. Endothelin-1 potentiates capsaicin-induced TRPV1 currents via the endothelin A receptor. Exp Biol Med (Maywood). 2006; 231:1161-1164. [PubMed: 16741069]

61. Reddy VB, Iuga AO, Shimada SG, LaMotte RH, Lerner EA. Cowhage-evoked itch is mediated by a novel cysteine protease: a ligand of protease-activated receptors. J Neurosci. 2008; 28:43314335. [PubMed: 18434511]

62. Ross SE, Mardinly AR, McCord AE, Zurawski J, Cohen S, Jung C, Hu L, Mok SI, Shah A, Savner EM, Tolias C, Corfas R, Chen S, Inquimbert P, Xu Y, McInnes RR, Rice FL, Corfas G, Ma Q, Woolf CJ, Greenberg ME. Loss of Inhibitory Interneurons in the Dorsal Spinal Cord and Elevated Itch in Bhlhb5 Mutant Mice. Neuron. 2010; 65:886-898. [PubMed: 20346763]

63. Scherrer G, Low SA, Wang X, Zhang J, Yamanaka H, Urban R, Solorzano C, Harper B, Hnasko TS, Edwards RH, Basbaum AI. VGLUT2 expression in primary afferent neurons is essential for 
normal acute pain and injury-induced heat hypersensitivity. Proc Natl Acad Sci U S A. 2010; 107:22296-22301. [PubMed: 21135246]

64. Schmelz M, Schmidt R, Bickel A, Handwerker HO, Torebjork HE. Specific C-receptors for itch in human skin. J Neurosci. 1997; 17:8003-8008. [PubMed: 9315918]

65. Shelley WB, Arthur RP. Mucunain, the active pruritogenic proteinase of cowhage. Science. 1955; 122:469-470. [PubMed: 13255877]

66. Shim WS, Oh U. Histamine-induced itch and its relationship with pain. Mol Pain. 2008; 4:29. [PubMed: 18667087]

67. Shim WS, Tak MH, Lee MH, Kim M, Kim M, Koo JY, Lee CH, Kim M, Oh U. TRPV1 mediates histamine-induced itching via the activation of phospholipase A2 and 12-lipoxygenase. J Neurosci. 2007; 27:2331-2337. [PubMed: 17329430]

68. Shimada SG, LaMotte RH. Behavioral differentiation between itch and pain in mouse. Pain. 2008; 139:681-687. [PubMed: 18789837]

69. Shumyatsky GP, Tsvetkov E, Malleret G, Vronskaya S, Hatton M, Hampton L, Battey JF, Dulac C, Kandel ER, Bolshakov VY. Identification of a signaling network in lateral nucleus of amygdala important for inhibiting memory specifically related to learned fear. Cell. 2002; 111:905-918. [PubMed: 12526815]

70. Sowunmi A, Walker O, Salako LA. Pruritus and antimalarial drugs in Africans. Lancet. 1989; 2:213. [PubMed: 2568535]

71. Spike RC, Puskar Z, Andrew D, Todd AJ. A quantitative and morphological study of projection neurons in lamina I of the rat lumbar spinal cord. Eur J Neurosci. 2003; 18:2433-2448. [PubMed: 14622144]

72. Steinhoff M, Neisius U, Ikoma A, Fartasch M, Heyer G, Skov PS, Luger TA, Schmelz M. Proteinase-activated receptor-2 mediates itch: a novel pathway for pruritus in human skin. J Neurosci. 2003; 23:6176-6180. [PubMed: 12867500]

73. Steinhoff M, Vergnolle N, Young SH, Tognetto M, Amadesi S, Ennes HS, Trevisani M, Hollenberg MD, Wallace JL, Caughey GH, Mitchell SE, Williams LM, Geppetti P, Mayer EA, Bunnett NW. Agonists of proteinase-activated receptor 2 induce inflammation by a neurogenic mechanism. Nat Med. 2000; 6:151-158. [PubMed: 10655102]

74. Story GM, Peier AM, Reeve AJ, Eid SR, Mosbacher J, Hricik TR, Earley TJ, Hergarden AC, Andersson DA, Hwang SW, McIntyre P, Jegla T, Bevan S, Patapoutian A. ANKTM1, a TRP-like channel expressed in nociceptive neurons, is activated by cold temperatures. Cell. 2003; 112:819829. [PubMed: 12654248]

75. Sun YG, Chen ZF. A gastrin-releasing peptide receptor mediates the itch sensation in the spinal cord. Nature. 2007; 448:700-703. [PubMed: 17653196]

76. Sun YG, Zhao ZQ, Meng XL, Yin J, Liu XY, Chen ZF. Cellular basis of itch sensation. Science. 2009; 325:1531-1534. [PubMed: 19661382]

77. Thurmond RL, Gelfand EW, Dunford PJ. The role of histamine H1 and H4 receptors in allergic inflammation: the search for new antihistamines. Nat Rev Drug Discov. 2008; 7:41-53. [PubMed: 18172439]

78. Tsujii K, Andoh T, Lee JB, Kuraishi Y. Activation of proteinase-activated receptors induces itchassociated response through histamine-dependent and -independent pathways in mice. J Pharmacol Sci. 2008; 108:385-388. [PubMed: 18987429]

79. Vergnolle N, Bunnett NW, Sharkey KA, Brussee V, Compton SJ, Grady EF, Cirino G, Gerard N, Basbaum AI, Andrade-Gordon P, Hollenberg MD, Wallace JL. Proteinase-activated receptor-2 and hyperalgesia: A novel pain pathway. Nat Med. 2001; 7:821-826. [PubMed: 11433347]

80. Woo DH, Jung SJ, Zhu MH, Park CK, Kim YH, Oh SB, Lee CJ. Direct activation of transient receptor potential vanilloid 1(TRPV1) by diacylglycerol (DAG). Mol Pain. 2008; 4:42. [PubMed: 18826653]

81. Xie W, Samoriski GM, McLaughlin JP, Romoser VA, Smrcka A, Hinkle PM, Bidlack JM, Gross RA, Jiang H, Wu D. Genetic alteration of phospholipase $\mathrm{C}$ beta3 expression modulates behavioral and cellular responses to mu opioids. Proc Natl Acad Sci U S A. 1999; 96:10385-10390.

[PubMed: 10468617] 